\title{
GRB10 wt Allele
}

National Cancer Institute

\section{Source}

National Cancer Institute. GRB10 wt Allele. NCI Thesaurus. Code C52391.

Human GRB10 wild-type allele is located within 7p12-p11.2 and is approximately $203 \mathrm{~kb}$ in length. This allele, which encodes growth factor receptor-bound protein 10, plays a role in the modulation of signaling from both insulin and insulin-like receptor tyrosine kinases. 